\title{
Risk-Adjusted Credit Pricing: Application to the state's guarantee funds for Moroccan enterprises
}

\section{Tarification du crédit ajustée en fonction des risques: application aux fonds de garantie de l'État pour les entreprises marocaines}

\author{
OUSSOUADI Kamal \\ PhD Student \\ Mohammed V University of Rabat (FSJES - SALE) \\ Laboratory: Finance, Entrepreneuriat and Development \\ oussouadi.kamal@,gmail.com

\section{CHERKAOUI Kenza} \\ Researcher Professor \\ Mohammed V University of Rabat (FSJES - SALE) \\ Laboratory: Finance, Entrepreneuriat and Development \\ kencherkaoui@,yahoo.fr
}

Date de soumission : 06/07/2020

Date d'acceptation : 15/09/2020

Pour citer cet article :

OUSSOUADI K. \& CHERKAOUI K. (2020) «Risk-Adjusted Credit Pricing: Application to the state's guarantee funds for Moroccan enterprises », Revue du contrôle, de la comptabilité et de l'audit «Volume 4 : numéro 3 »p : $485-505$. 
Revue du Contrôle de la Comptabilité et de l'Audit

ISSN: 2550-469X

Volume 4 - Numéro 3

\section{Abstract}

Authorities' intervention is key to facilitating access to sources of finance for small and medium enterprises (SMEs). Credit guarantee is a viable solution that is more conducive to bringing the financing needs of SMEs closer to the demands of the financial sector. However, the sustainability of any guarantee system depends on its ability to balance between its resources and its jobs, i.e. the equality between the indemnifications of the losses due to credit risk on the one hand and the commissions, the investment products and laps on the other side. As a result, the fee structure of the guarantee commission must be able to cover a part of the financial charges resulting from the operation of the guarantee of the credits, namely the cover of the credit risk and the management cost.

This work introduces a new approach to assess the cost of the guarantee taking into account the cost of credit risk and the cost of management.

Keywords: Credit risk, internal rating, expected losses, Guarantee Fund, small and medium enterprises.

\section{Résumé}

L'intervention des pouvoirs publics est fondamentale pour faciliter aux très petites, petites et moyennes entreprises (PME) l'accès aux sources de financement. La garantie des crédits forme une solution viable qui favorise davantage le rapprochement des besoins de financement des PME avec les exigences du secteur financier.

Toutefois, la pérennité de tout système de garantie dépend sur sa capacité d'équilibrer entre ses ressources et ses emplois, soit l'égalité entre les indemnisations des pertes dues au risque de crédit d'un côté et les commissions, les produits de placement et les recouvrements de l'autre côté.

De ce fait, le dispositif de tarification de la commission de la garantie doit être en mesure de couvrir une partie des charges financières résultantes de l'opération de la garantie des crédits, à savoir la couverture du risque de crédit et du coût de gestion.

Ce travail présente une nouvelle démarche pour évaluer le coût de la garantie en tenant compte le coût du risque de crédit et de gestion.

Mots clés : Risque de crédit, notation interne, pertes attendues, Fonds de garantie, petites et moyennes entreprises 
Revue du Contrôle de la Comptabilité et de l'Audit ISSN: 2550-469X

Volume 4 - Numéro 3

\section{Introduction}

Guarantee funds, especially those geared towards SMEs, make a significant contribution to making bank loans available for this category of companies. Several viable projects find it difficult to access financing, generally due to a lack of coverage of the loans presented by their promoters. It is at this level that the Guarantee Funds fully play their role for the national economy by offering risk sharing with banks and motivating them to explore new market segments. They thus make it possible to redirect investments towards the sectors considered important for economic growth and job creation.

In the Moroccan context, the following questions should be asked:

- What public intervention to fight against the rationing of bank credit?

- This mode of intervention must be well calibrated in order to be effective, in which way?

To fight against this risk of credit rationing, must be assumed by state part of the credit risk through a guarantee system. In order to properly target public intervention, it is necessary to identify the level of risk at which access to bank credit to be likely rationed. Since such information is not directly observable. A hypothesis is constructed from the observation of certain pricing practices. theoretically, the level of credit risk can be observed in the rates charged by banks on credit. Since they incorporate the risk premium, which can be calculated directly according to risk indicators. Once the public intervention target has been chosen. There modelling can provide a first estimate of what the optimal pricing of the guarantee, then should be. Thus, the price of the guarantee must also be sufficiently close to reality of the costs. economy and job creation.

To summarize, the problematic can be formulated in the following terms:

The Guarantee Fund, is it capable of balancing its resources and its uses? i.e. the equality between the inde mnifications of the losses due to the credit risk on the one hand and the commissions, the products of placement and overlays on the other side?

As a result, the fee structure of the guarantee commission must be able to cover a part of the financial charges resulting from the operation of the guarantee of the credits, namely the cover of the credit risk and the management cost. To address this problem, we present in the document an approach based on the internal default risk rating for the estimation of the cost of risk on the one hand and on the other hand, an analytical approach based on managementrelated aggregates for estimate the operational cost of the guarantee. 


\section{National guarantee scheme for companies}

The existence of a strong SME fabric is a determining factor for the development of the countries, because it acts on the economic growth but also on the social and political stability. However, the access of this category to financing often remains a difficult obstacle to overcome. This problem of access to finance for SMEs is worrying public authorities and encourages them to find sustainable ways to circumvent it. Among the devices used around the world, there is the guarantee of credits that consists of sharing the risk of default of the customer or the project with the bank. Guarantee schemes have been designed to overcome the problem of lack of collateral (which is a requirement for the bank to access financing) by offering surety bonds. They have a social and economic role and position themselves as interfaces between applicants and credit providers.

\section{SME credit guarantee systemin Morocco}

In Morocco, the public authorities have embarked in recent years on a vast reform program aimed at boosting investment, modernizing businesses, youth self-employment and promoting social housing for modest or irregular income-earning populations.

The Central Guarantee Fund (CGF), as an instrument of state intervention in economic and social policy, is at the heart of this support system through a diversified product offering serving businesses and individuals. The CGF's corporate guarantee also positions itself as an important player in the promotion of the economy, through a guarantee product offering adapted to the financing needs of the SMEs, both for their investment project and their operating cycle, expressed throughout their life cycle:

Table $\mathrm{N}^{\circ} 1$ : Product offering of the CGF

\begin{tabular}{|l|l|l|}
\hline Segment & Nature of needs & Guarantee products offer \\
\hline \multirow{3}{*}{ VSE } & Investment & Damane Express \\
\cline { 3 - 3 } & & Ilayki \\
\cline { 3 - 3 } & & Mouwakaba \\
\hline
\end{tabular}


Revue du Contrôle de la Comptabilité et de l'Audit ISSN: 2550-469X

Volume 4 - Numéro 3

\begin{tabular}{|c|c|c|}
\hline & Exploitation & Damane Express \\
\hline \multirow{9}{*}{ SME } & \multirow[t]{3}{*}{ Investment } & Damane Dev \\
\hline & & DamaneCrea \\
\hline & & Damane capital risqué \\
\hline & Exploitation & Damane Exploitation \\
\hline & Export & Damane Export \\
\hline & & Caution marchés à l'export \\
\hline & Restructuring & DamaneIstimrar \\
\hline & Transmission & Damane capital risqué \\
\hline & & Damane transmission \\
\hline
\end{tabular}

Source: Authors (on the basis of offer products of the CGF)

\section{SME Guarantee Fund (SMEGF)}

The SMEGF is created following the new strategy of the state to better support the Moroccan SME during its production cycle from creation to financial restructuring.

The SMEGF receives a commission calculated on the flat rate credit amount below with a minimum of $1.000,00 \mathrm{DH}^{1}$ :

Table N²: Guarantee Commission applied to the SMEGF

\begin{tabular}{|l|l|l|l|}
\hline Product & Maturity & Investment credits & Operating credits \\
\hline $\begin{array}{l}\text { Damane } \\
\text { EXPRESS }\end{array}$ & $\begin{array}{l}\text { Flat loan } \\
\text { commission (duty- } \\
\text { free) }\end{array}$ & $1,5 \%$ & $0,5 \%$ per operation \\
\hline
\end{tabular}

${ }^{1}$ Moroccan Dirham (MAD) 
Revue du Contrôle de la Comptabilité et de l'Audit ISSN: 2550-469X

Volume 4 - Numéro 3

\begin{tabular}{|c|c|c|c|}
\hline Damane CREA & $\begin{array}{l}\text { Flat loan } \\
\text { commission (duty- } \\
\text { free) }\end{array}$ & $2 \%$ flat (duty-free) & \\
\hline Damane DEV & $\begin{array}{l}\text { Flat loan } \\
\text { commission (duty- } \\
\text { free) }\end{array}$ & $\begin{array}{l}\text { In the event of a } \\
\text { ceiling on the } \\
\text { guarantee, the basis } \\
\text { to be used is the } \\
\text { on the amount of } \\
\text { equivalent of the } \\
\text { credit corresponding } \\
\text { to the guarantee } \\
\text { given. }\end{array}$ & \\
\hline $\begin{array}{l}\text { Damane } \\
\text { Exploitation } \\
\text { And } \\
\text { Damane } \\
\text { Restructuration }\end{array}$ & $\begin{array}{l}\text { Flat loan } \\
\text { commission (duty- } \\
\text { free) }\end{array}$ & & $\begin{array}{l}0,5 \% \text { flat (duty-free) by } \\
\text { operation calculated on } \\
\text { the amount of the credit. } \\
\text { In the event of a ceiling } \\
\text { on the guarantee, the } \\
\text { base to be used is the } \\
\text { equivalent of the credit } \\
\text { corresponding to the } \\
\text { guarantee given }\end{array}$ \\
\hline
\end{tabular}

Source: Authors (on the basis of offer products of the CGF) 
Revue du Contrôle de la Comptabilité et de l'Audit ISSN: 2550-469X

Volume 4 - Numéro 3

The analysis of the fees charged on the SMEGF's operations and the comparison with the other existing guarantee organizations show that the CGF generally applies guarantee commission rates much lower than all the comparators.

It is therefore necessary to review the grid of the commission applied to better adapt to the risk taken and the operational cost of the guarantee. The following section deals with this problem and proposes a new approach to estimate the commission of the guarantee.

Risk-based pricing and management of the SMEGF Enterprise Portfolio transactions

The SME credit guarantee is a risk sharing of losses between the financial institution (bank) and the guarantee institution. This requires a good risk control by the guarantor as well as having models of quantification of default of payment posteriori like the models established in the banks. The pricing of the cost of credit applied by the banks differs according to the commercial policy of each bank, and according to its action with respect to the risk of default. Among the approaches taken by banks to es timate the cost of credit, there is the one based on the credit risk quantification model, through the estimation of expected and unanticipated losses at well-defined horizons. In this second part, we will try to use the same structure of the cost of credit applied by the bank to approach the cost of the guarantee thus integrating the peculiarity of guarantee scheme and its financial model.

\section{Components of the cost of the guarantee}

The credit price results from the cost structure and the margin of the bank, namely:

$\checkmark$ Cost of refinancing,

$\checkmark$ Management cost (operational costs): operating costs reflecting activities related to the granting and management of loans (monitoring and advice, real estate appraisals, balance sheet processing, etc.)

$\checkmark$ Cost of risk:

- Expected losses: analytical cost resulting from ratings (probability of default) and losses in case of default;

- Unexpected losses or the cost of equity: Minimum capital requirements for credit activity (role of absorbing "unexpected" losses).

Regarding the reconciliation of the cost of the guarantee, certain assumptions must be formulated: 
Revue du Contrôle de la Comptabilité et de l'Audit ISSN: 2550-469X

Volume 4 - Numéro 3

- It is assumed that the expected losses and the operational cost will be covered by the guarantee commission;

- It is assumed that the unexpected losses must be covered by the endowments;

- In the case of a Guarantee Fund, the cost of refinancing will not be taken into account, since the guarantee model used assumes that the guarantor receives the grants free of charge.

The cost of the guarantee that will be estimated in this study is as follows:

\section{Cost of the guarantee $=$ Cost of the risk (expected losses $)+$ Management cost}

\section{Guaranteed credit risk cost calculation approach}

The approach chosen for calculating the cost of risk is the estimate of the present value of the losses that can be generated by a guarantee transaction.

To this end, the CGF's own credit risk quantification model will be used to generate the parameters needed to calculate the loss and which are:

- The probability of default (PD)

- The loss given default (LGD)

- The exposure at default (EAD)

The calculation to be done according to the following process can be summarized as follows:

Figure $\mathrm{N}^{\circ} 1$ : Approach to calculate the cost of risk

- Business Portfolio

Segmentation by

Rating Class

- Probability of cumulative defects

by rating class

- Probability of

default by risk class

\section{Probability of} default

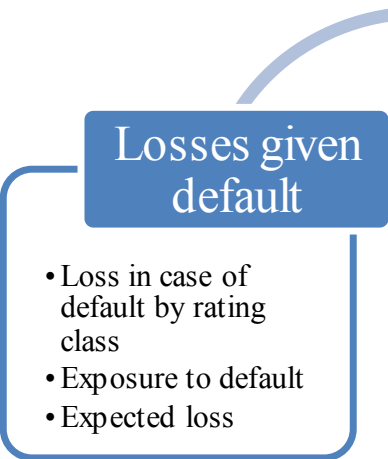

Expected loss
- Current value of losses by rating class

- Cost of risk for 1 credit DH given

\section{Cost of the} risk

\section{Source: Authors}

\subsection{Definition of the Probability of Default (PD)}

The probability of default (PD) is defined as a measure of the probability that a transaction will default on its payments in the next year (or the time horizon chosen). 
Revue du Contrôle de la Comptabilité et de l'Audit ISSN: 2550-469X

Volume 4 - Numéro 3

The probability of default is usually measured by means of a counterparty rating so that:

- Each borrower is noted;

- All counterparties within a single rating form a risk class.

Each rating is assigned a unique default probability: all counterparties with a given rating receive the default probability associated with that rating.

\subsection{Definition of rating classes}

It is a question of calculating the probabilities associated with each of the rating classes (risk class): this is the number of defects that have occurred over a year for a credit category, divided by the number of loans in that category.

The choice of the rating classes is based on the segmentation of score classes obtained at the time of the grant, according to the default generated during well-defined horizons (in months for example). The process used is the decision tree of the SPAD statistical tool.

The cutting element or "driver" that was taken into account for risk group segmentation was the score obtained by the corresponding grant model.

\subsection{Calculation of the loss given default (LGD)}

The loss given default (LGD) corresponds to the actual loss expected in case of default. This is the portion of the unrecovered debt, expressed as a percentage.

The formula is the following: LGD $=\mathbf{1 0 0} \%$ - Recovered (percentage)

\subsection{The exposure at default (EAD)}

The EAD is the amount owed by the counterparty when it will de fault on a given commitment to a horizon corresponding to that used for the probability of default.

\subsection{Expected losses (EL)}

Each credit institution evaluates the amount that it may lose on average on its loan portfolio over a given horizon. This amount corresponds to "expected losses" and is theoretically covered by provisions.

For each line of credit, this loss is a function of the probability of default (likelihood of default occurring). The exposure on the date of default (EAD), that is, the amount of capital remaining due in the case of a standard credit, and the loss given default (LGD) which depends on the rate of recovery on a loan that has defaulted.

The expected loss is therefore a function of the following three parameters:

$$
\mathrm{EL}=\mathrm{PD} \times \mathrm{LGD} \times \mathrm{EAD}
$$


Revue du Contrôle de la Comptabilité et de l'Audit

ISSN: $2550-469 X$

Volume 4 - Numéro 3

\subsection{Calculation of the cost of default risk}

The cost of risk of a credit dirham is the sum of the current values net of expected losses during the life of credit.

$$
\text { Cost }- \text { of }- \text { risk }=\sum_{t=1}^{n} V A N\left(E L_{-}(t)\right)
$$

\section{Approach for calculating the cost of management}

In the absence of cost accounting within the CGF, the expense resulting from a guarantee transaction can be estimated by defining the allocation keys for each segment of the portfolio, based on the following aggregates:

- Overall payroll

- Payroll of the business service Granting of the SME credit guarantee

- Support service payroll

- Overall operating expenses

- Outstanding portion of the guaranteed portfolio segments SME

In our case, depending on the availability of the information, the distribution key will be a percentage of the wage bill related to the production of the grant of the guarantee as well as that related to the service of the support reported on the overall weight of the CGF.

Once the keys have been defined, the calculation of the annual management charge will be based on a percentage of the outstanding amortization for each year for an average life of credit.

The management cost of year $t$ will therefore be defined as:

$\mathrm{CM}(\mathrm{t})=$ Cost of management $(\mathrm{t})=\frac{\mathrm{CE}(\mathrm{t}) \text { of segment } \mathrm{S}_{\mathrm{i}}}{\text { Outstanding at the end of the year } \mathrm{t} \text { of segments }}$

$\mathrm{CM}(\mathrm{t})$ : cost of management of the year $\mathrm{t}$

$\mathrm{CE}(\mathrm{t})$ : runnig costs of yeat $\mathrm{t}$

The final management cost will therefore be the sum of the updated values of the annual management costs:

$$
\text { Management Cost }=\sum_{t=1}^{n} \operatorname{VAN}(C G(t))
$$


Revue du Contrôle de la Comptabilité et de l'Audit ISSN: 2550-469X

\section{Applying the Credit Risk Adjustment Pricing Approach to CGF Data, SME Portfolio}

\subsection{Scope and calculation assumptions}

PD segmentation will follow the same segmentation applied to the CGF for the quantification of credit risk, namely:

○ The start-ups segment VSE: S1

- The start-ups segment SME: S2

- The non-start-ups segment VSE: S3

○ The non-start-ups segment SME: S4

The characteristics of these segments are summarized in the table below:

Table N³: Characteristics of the SMEGF Enterprise Portfolio Segments

\begin{tabular}{|c|c|c|c|c|}
\hline Segment & $\begin{array}{l}\text { Company's } \\
\text { type }\end{array}$ & Company' size & Finality & $\begin{array}{l}\text { Associated } \\
\text { product }\end{array}$ \\
\hline S1 & Start-ups & $\begin{array}{l}\text { Size of VSE linked to } \\
\text { the amount of credit } \\
\text { granted which must } \\
\text { not exceed one million } \\
\text { DH }\end{array}$ & Creation & $\begin{array}{l}\text { Damane express } \\
\text { Capital risque }\end{array}$ \\
\hline S2 & Start-ups & $\begin{array}{l}\text { Size of VSE linked to } \\
\text { the amount of credit } \\
\text { granted which must } \\
\text { not exceed one million } \\
\text { DH }\end{array}$ & Creation & Damane creation \\
\hline S3 & Non-start-ups & $\begin{array}{l}\text { VSE size linked to the } \\
\text { amount of credit } \\
\text { granted greater than } 1 \\
\text { million DH }\end{array}$ & $\begin{array}{l}\text { Development, } \\
\text { Exploitation } \\
\text { or } \\
\text { restructuration }\end{array}$ & Damane Express \\
\hline
\end{tabular}




\begin{tabular}{|l|l|l|l|l|}
\hline \multirow{2}{*}{ S4 } & \multirow{2}{*}{ Non-start-ups } & $\begin{array}{l}\text { VSE size linked to the } \\
\text { amount of credit } \\
\text { granted greater than 1 } \\
\text { million DH }\end{array}$ & $\begin{array}{l}\text { Development, } \\
\text { Exploitation } \\
\text { or }\end{array}$ & Damane \\
& restructuration & Développement, \\
& Damane \\
& & Exploitation, \\
& & \\
\hline
\end{tabular}

\section{Source: Authors}

- For the LGD calculation: CGF has a predefined LGD model;

- For the EAD calculation: the exposure will be based on a depreciation of $1 \mathrm{DH}$ of credit over an average credit period and an average interest rate recorded on the studied portfolio;

- The yield curve used to discount future losses will be the one fixed on the BANK ALMAGHRIB website.

- For the calculation of the management costs, the data used will be those stopped at the end of 2016.

- The mode chosen for the application of the commission is a flat fraction according to the amount of credit to guarantee.

- The technique chosen for guarantee fee pricing depends mainly on the credit risk rating models. The following section provides an overview of the CGF's internal models.

\subsection{Calculation of the probability of default by risk class}

\subsubsection{Definition of default}

The default definition used is consistent with that used in the CGC models.

There will be a default if the activation of the guarantee is activated, in other words, if the secured credit is in litigation with the bank.

\subsubsection{Preparation and data processing}

To calculate the PD by rating class, the sample data from the Enterprise Warranty portfolio was used, which includes the score carded warranty records and default information for "images" of transactions between March 31, 1998. June 30, 2016. The main applied filters are applied:

- Records that have a depreciation of $100 \%$ are eliminated.

- Records are eliminated before the operation is granted.

- Records that do not contain any known score values are discarded. 
Revue du Contrôle de la Comptabilité et de l'Audit ISSN: $2550-469 X$

Volume 4 - Numéro 3

This estimation sample $(7,189$ transactions) will serve as a basis for segmentation into risk groups. Samples are classified as follows for PD:

\section{Figure $\mathrm{N}^{\circ}$ 2: Segmentation by risk groups}

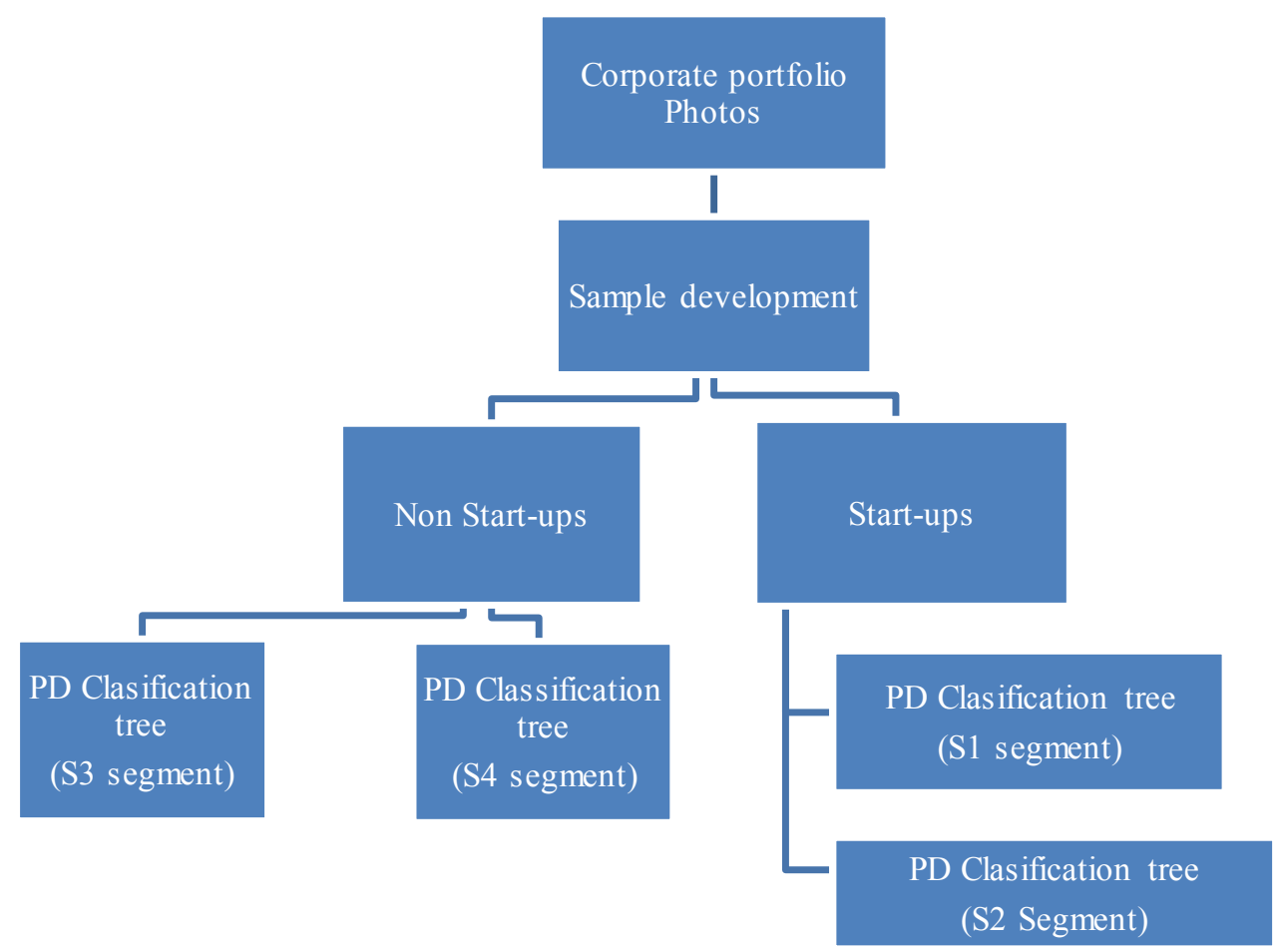

\section{Source: Authors}

\subsubsection{Rating class}

\subsubsection{Portfolio segmentation in rating class}

A very important aspect in calculating the probability of default is the segmentation of the portfolio into sub-portfolios of homogeneous action in terms of credit risk.

You do not get a single PD value for the entire portfolio, but one for each risk subgroup.

The scoring element that has been taken into account for risk group segmentation was the score obtained by the scoring model implemented at the grant business process level, namely:

- A model for granting VSEs for the creation purpose (VSE start-up)

- A model for granting SMEs for the creation purpose (SME start-up)

- A model for granting VSEs outside the creation purpose (Not start-up VSE)

- A model for granting SMEs outside the creation purpose (Not start-up SME) 
Revue du Contrôle de la Comptabilité et de l'Audit ISSN: 2550-469X

Volume 4 - Numéro 3

\subsubsection{Presentation of Default Probability by Rating Class}

The default probabilities by rating class (CRi) for each of the above segments of the Enterprise portfolio are as follows.

- Estimation of future exposure to the risk of default :

Future exposure is simulated from loss rates and down payments by year. The reduction in outstanding amounts is calculated through the theoretical amortization of a loan using an average interest rate and an average credit duration observed during the last three years of the portfolio (from 2011 onwards). The credit data for each segment of the portfolio is:

Table N4: Enterprise Portfolio Credit Characteristics by Segment

\begin{tabular}{|l|l|l|}
\hline Segment & $\begin{array}{l}\text { Average credit } \\
\text { duration in years }\end{array}$ & $\begin{array}{l}\text { Average interest } \\
\text { rate }\end{array}$ \\
\hline S1 & 8 & $7,3 \%$ \\
\hline S2 & 8 & $7,2 \%$ \\
\hline S3 & 7 & $8,3 \%$ \\
\hline S4 & 7 & $7,2 \%$ \\
\hline
\end{tabular}

\section{Source: Authors}

The amortization of a 1 dirham of credit throughout the term of the loan according to the characteristics of each segment is as follows:

Table N05: Annual amortization of one credit dirham by segment

\begin{tabular}{|l|l|l|l|l|l|l|l|l|l|}
\hline \multicolumn{7}{|c|}{ Annual amortization } \\
\hline Segment & $\mathbf{0}$ & $\mathbf{1}$ & $\mathbf{2}$ & $\mathbf{3}$ & $\mathbf{4}$ & $\mathbf{5}$ & $\mathbf{6}$ & $\mathbf{7}$ & $\mathbf{8}$ \\
\hline S1 & 1,00 & 0,90 & 0,80 & 0,69 & 0,57 & 0,44 & 0,31 & 0,16 & 0,00 \\
\hline S2 & 1,00 & 0,90 & 0,80 & 0,69 & 0,57 & 0,44 & 0,30 & 0,16 & 0,00 \\
\hline S3 & 1,00 & 0,89 & 0,77 & 0,64 & 0,50 & 0,34 & 0,18 & 0,00 & - \\
\hline
\end{tabular}


Revue du Contrôle de la Comptabilité et de l'Audit ISSN: 2550-469X

\begin{tabular}{|l|l|l|l|l|l|l|l|l|l|}
\hline S4 & 1,00 & 0,89 & 0,76 & 0,63 & 0,49 & 0,34 & 0,17 & 0,00 & - \\
\hline
\end{tabular}

\section{Source: Authors}

\subsection{Calculation of the LGD}

The LGD used to calculate the expected losses is the one used in the CGF's risk quantification model and takes different values depending on the classification of the portfolio:

\section{Figure N³: Loss Given Default (LGD) per segment}

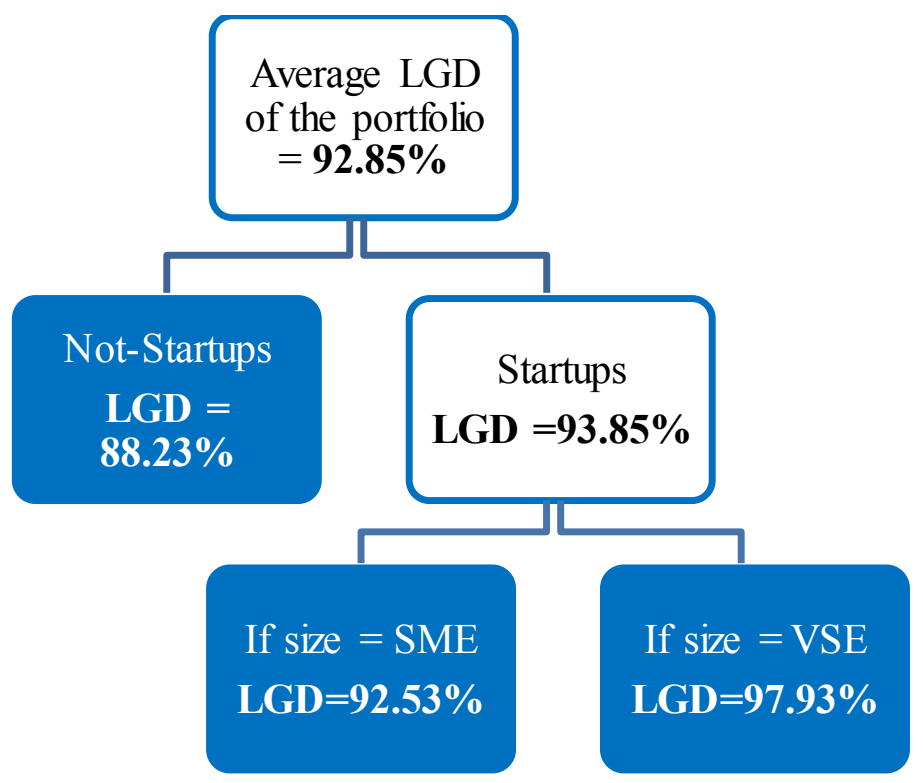

Source: Authors

\subsection{Calculation of expected losses}

The expected loss is the multiplication of the probability of default by the recovery rate and the risk exposure:

$$
\mathrm{EL}=\mathrm{PD} \times \mathrm{LGD} \times \mathrm{EAD}
$$

Where

$$
\begin{aligned}
& E L=\text { Expected losses } \\
& \mathrm{PD}=\text { Probability of default } \\
& \text { LGD = Loss Given Default } \\
& \mathrm{EAD}=\text { Exposure at default }
\end{aligned}
$$


Revue du Contrôle de la Comptabilité et de l'Audit ISSN: 2550-469X

Volume 4 - Numéro 3

The objective of calculating the probability of default for each year is the estimate of future net loss flows that the SME guarantee fund may incur for a guarantee transaction.

The following tables present the amount of the losses due to the failure to pay for $100 \mathrm{DH}$ of credit granted:

Table $N^{\circ} 6$ : Amount of expected losses for the S1 Segment

\begin{tabular}{|l|l|l|l|l|l|l|l|}
\hline \multirow{2}{*}{ Segment S1 } & \multicolumn{6}{|l|}{ Loss flow for 100 DH } \\
& \multicolumn{2}{l|}{ during the year y } \\
\hline & $\mathbf{1}$ & $\mathbf{2}$ & $\mathbf{4}$ & $\mathbf{5}$ & $\mathbf{6}$ & $\mathbf{7}$ & $\mathbf{8}$ \\
\hline CR1 & 1,579 & 0,548 & 0,043 & 0,041 & 0,039 & 0,013 & 0,012 \\
\hline CR2 & 1,125 & 0,260 & 0,020 & 0,020 & 0,019 & 0,018 & 0,017 \\
\hline CR4 & 0,800 & 0,043 & 0,038 & 0,037 & 0,035 & 0,029 & 0,027 \\
\hline
\end{tabular}

\section{Source: Authors}

\section{For the SME Start-ups segment}

Table No7: Amount of expected losses for the S2 Segment

\begin{tabular}{|l|l|l|l|l|l|l|l|}
\hline \multirow{2}{*}{$\begin{array}{l}\text { Segment } \\
\text { S1 }\end{array}$} & \multicolumn{6}{|l|}{ Loss flow for $100 \mathrm{DH}$} \\
during the year y & \multicolumn{5}{l|}{} \\
\cline { 2 - 8 } & $\mathbf{1}$ & $\mathbf{2}$ & $\mathbf{4}$ & $\mathbf{5}$ & $\mathbf{6}$ & 7 & $\mathbf{8}$ \\
\hline CR1 & 0,258 & 0,057 & 0,002 & 0,002 & 0,002 & 0,012 & 0,011 \\
\hline CR2 & 0,062 & 0,074 & 0,013 & 0,012 & 0,012 & 0,013 & 0,013 \\
\hline
\end{tabular}


Revue du Contrôle de la Comptabilité et de l'Audit ISSN: 2550-469X

Volume 4 - Numéro 3

Source: Authors

\begin{tabular}{|l|l|l|l|l|l|l|l|}
\hline CR3 & 0,066 & 0,038 & 0,007 & 0,007 & 0,006 & 0,006 & 0,006 \\
\hline
\end{tabular}

Table N8: Amount of expected losses for the S3 Segment

\begin{tabular}{|c|c|c|c|c|c|c|}
\hline \multirow[t]{2}{*}{ Segment S1 } & \multicolumn{6}{|c|}{$\begin{array}{l}\text { Loss flow for } 100 \mathrm{DH} \\
\text { during the year } \mathrm{y}\end{array}$} \\
\hline & 1 & 2 & 4 & 5 & 6 & 7 \\
\hline CR1 & 0,644 & 0,040 & 0,033 & 0,031 & 0,029 & 0,028 \\
\hline CR2 & 0,328 & 0,074 & 0,021 & 0,020 & 0,019 & 0,018 \\
\hline CR3 & 0,247 & 0,059 & 0,018 & 0,017 & 0,016 & 0,016 \\
\hline CR4 & 0,084 & 0,021 & 0,017 & 0,016 & 0,016 & 0,015 \\
\hline
\end{tabular}

Source: Authors

Table No9: Amount of expected losses for the S4 Segment

\begin{tabular}{|l|l|l|l|l|l|l|}
\hline \multirow{2}{*}{ Segment S1 } & \multicolumn{5}{|l|}{ Loss flow for 100 DH } \\
& \multicolumn{2}{l|}{ during the year y } \\
\cline { 2 - 7 } & $\mathbf{1}$ & $\mathbf{2}$ & $\mathbf{4}$ & $\mathbf{5}$ & $\mathbf{6}$ & $\mathbf{7}$ \\
\hline CR1 & 0,512 & 0,035 & 0,001 & 0,001 & 0,001 & 0,001 \\
\hline CR2 & 0,144 & 0,026 & 0,002 & 0,002 & 0,002 & 0,002 \\
\hline CR3 & & & & & & \\
\hline
\end{tabular}


Revue du Contrôle de la Comptabilité et de l'Audit ISSN: 2550-469X

Source: Authors

\subsection{Cost of risk by segment and rating class}

After calculating expected loss flows at different future dates, the cost of risk for each segment will be as follows:

$$
\text { Cost of risk }=\sum_{k=0}^{n} \operatorname{VAN}\left(\mathrm{EL}_{\mathrm{t}}\right)
$$

With:

$$
\operatorname{VAN}\left(\mathrm{EL}_{\mathrm{t}}\right)=\frac{E L_{t}}{(1+\rho)^{t-1}}
$$

EL $t$ : flow of expected losses for the year of credit $t$

The calculation of the present value of the loss will be based on the series of the rate curve. This choice is justified by taking into account the effect of inflation in the calculation of the cost of risk at the time of the granting of the guarantee.

The yield curve presented in the BANK AL-MAGHRIB site is daily, hence the use of the linear interpolation technique to calculate the discount rate of the annual horizons.

The rates used in the update will be:

\begin{tabular}{|l|l|}
\hline $\begin{array}{l}\text { Maturity(in } \\
\text { years) }\end{array}$ & \\
\hline 1 & $3,910 \%$ \\
\hline 2 & $4,381 \%$ \\
\hline 3 & $4,589 \%$ \\
\hline 4 & $4,589 \%$ \\
\hline 5 & $4,845 \%$ \\
\hline 6 & $4,845 \%$ \\
\hline 7 & $4,845 \%$ \\
\hline 8 & $4,845 \%$ \\
\hline
\end{tabular}


Revue du Contrôle de la Comptabilité et de l'Audit ISSN: 2550-469X

Volume 4 - Numéro 3

Hereinafter, the cost of risk matrix by segment and rating class.

Table $\mathrm{N}^{\circ} 10$ : Cost of risk by rating clas $\mathrm{S}$

\section{Source: Authors}

\begin{tabular}{|l|l|l|l|l|}
\hline Segment/CR & CR1 & CR2 & CR3 & CR4 \\
\hline S1 & $2,17 \%$ & $1,42 \%$ & $0,94 \%$ & $0,55 \%$ \\
\hline S2 & $0,32 \%$ & $0,17 \%$ & $0,12 \%$ & \\
\hline S3 & $0,74 \%$ & $0,43 \%$ & $0,33 \%$ & $0,13 \%$ \\
\hline S4 & $0,54 \%$ & $0,17 \%$ & $0,06 \%$ & \\
\hline
\end{tabular}

\subsection{Cost of management estimation by segment}

According to the method previously mentioned, the cost of management per segment will be:

Table $\mathrm{N}^{\circ} 11$ : Cost of management per segment

\begin{tabular}{|l|l|}
\hline Segment & $\begin{array}{l}\text { Associated cost } \\
\text { of management }\end{array}$ \\
\hline S1 & $1,33 \%$ \\
\hline S2 & $1,31 \%$ \\
\hline S3 & $1,09 \%$ \\
\hline S4 & $1,13 \%$ \\
\hline
\end{tabular}

Source: Authors

\subsection{Final Fee Schedule of the Guarantee Commission}

After calculating the cost of risk and the cost of management per segment, the new rates of the commission will be: 
Revue du Contrôle de la Comptabilité et de l'Audit ISSN: 2550-469X

Volume 4 - Numéro 3

Table N¹2: Guarantee Fee Cost by Segment and Grade Rating

\begin{tabular}{|c|c|c|c|c|}
\hline Segment/CR & CR1 & CR2 & CR3 & CR4 \\
\hline S1 & $3,50 \%$ & $2,74 \%$ & $2,27 \%$ & $1,88 \%$ \\
\hline S2 & $1,65 \%$ & $1,49 \%$ & $1,44 \%$ & \\
\hline S3 & $2,07 \%$ & $1,76 \%$ & $1,66 \%$ & $1,46 \%$ \\
\hline S4 & $1,87 \%$ & $1,50 \%$ & $1,38 \%$ & \\
\hline
\end{tabular}

The commission to be applied will therefore be a flat percentage on the guaranteed amount and will be based on the size of the company and its risk rating at the time of grant.

In addition, the comparison between the current scale and that proposed by the credit riskadjusted pricing shows that the high-risk segments will be charged more than the others.

Table $N^{\circ}$ 13: Current commission and that proposed by the credit risk-adjusted pricing

\begin{tabular}{|l|l|l|l|}
\hline Segment & Ass ociated product & $\begin{array}{l}\text { Current } \\
\text { commission }\end{array}$ & Offered commission \\
\hline S1 & Damane express & $1,5 \%$ & Max : $3,5 \%$ \\
\hline S2 & Damane création & $2 \%$ & Min : $2 \%$ \\
\hline S3 & Damane Express & $2 \%$ or $0,5 \%$ & Min : $1,5 \%$ \\
\hline S4 & $\begin{array}{l}\text { Damane Développement, } \\
\text { Damane Exploitation, }\end{array}$ & $2 \%$ or $0,5 \%$ & Max $: 2 \%$ \\
\hline
\end{tabular}


Revue du Contrôle de la Comptabilité et de l'Audit

ISSN: 2550-469X

Volume 4 - Numéro 3

\begin{tabular}{|l|l|l|l|}
\hline & Damane Istimrar & & \\
& & & \\
\hline
\end{tabular}

\section{Source: Authors}

\section{Conclusion}

The calculation results show that the operations of guaranteeing credits intended for the creation of a company generate a significant cost. This is due to cred it risk and the amount of human and technical resources mobilized for this tranche of business to access financing. In addition to allowing the cost of the guarantee to be evaluated at its fair value, credit riskadjusted pricing also gives the opportunity to measure the subsidy offered by the State through allocations to the corporate loan guarantee fund.

Also, the implementation of this pricing technique requires the involvement of all stakeholders in the guarantee namely the state (through the CGF), banks and contractors.

\section{REFERENCES BIBLIOGRAPHIQUES}

- Jonathan Berk-Peter DeMarzo, Finance d'entreprise, Editions PEARSON, Montréal, 2008 .

- John Hull, Gestion des risques et institutions financières, Editions PEARSON, Montréal, 2007.

- Michel DIETSCH et Joël PETEY, Mesure et gestion du risque de crédit, REVUE BANQUE EDITION

- GUIDE D’UTILISATIONDES PRODUITS DÉDIÉS A L'ENTREPRISE A L'USAGE de la Caisse Centrale de Garantie. Retrieved from http://www.rabatinvest.ma/sites/default/files/FichiersCRI/guide dutilisation des produit $\underline{\text { s de la ccg.pdf }}$

- GIZ: SMEs' Credit Guarantee Schemes in Developing and Emerging Economies. Reflections, Setting-up Principles, Quality Standards. March 2014. Retrieved from http://www.aecm.eu/servlet/Repository/giz-study-on-smes-credit-guaranteeschemes.pdf?IDR $=553$

- Thierry RONCALLI, Introduction à la gestion des risques, cours ENSAI de 3ème année. Retrieved from www.thierry-roncalli.com/download/Lecture-Notes-Copula-Ensai.pdf

- The activity report $(2013,2014,2015)$ of the CGF. Retrieved from www.ccg.ma 